\title{
Current Regulations for the Production of Multipotent Mesenchymal Stromal Cells for Clinical Application
}

\author{
Ineke C.M. Slaper-Cortenbach \\ UMC Utrecht, Utrecht Center for Gene and Cell Therapy, Utrecht, the Netherlands
}

\section{Key Words}

MSC · Regulatory issues · Advanced therapy medicinal products

\section{Summary}

In this review, the appropriate legislation on the expansion of multipotent mesenchymal stromal cells (MSCs) in Europe is described. The collection of cells and the manufacturing of MSCs are being regulated by European Directives (EUDs). Recently, the Regulation on Advanced Therapies Medicinal Products (ATMPs) is being published, which is of importance for the production of MSCs in Europe, and this legislation is not yet ready, but it is in its final stage. MSCs are currently being used in clinical trials, mostly in academic hospitals, for patients suffering from a wide variety of diseases. Companies (small and medium-sized enterprises) are becoming more and more involved in the production of MSCs for human use, and since marketing authorisation is the scope of the Regulation it was decided to install a Committee on Advanced Therapies (CAT) within European Medicines Agency (EMEA). This CAT will formulate a draft opinion on quality, safety and efficacy of ATMPs and will have an advisory and scientific role for the Committee for Medicinal Products for human use. The aim of this review is to outline the current legislation which is important for the manufacturing of MSCs.

\section{Schlüsselwörter}

MSC · Regulatorische Angelegenheiten · Medizinische Produkte für fortgeschrittene Therapie

\section{Zusammenfassung}

In dieser Übersicht wird die zugehörige Gesetzgebung für die Vermehrung/Expansion der multipotenten mesenchymalen Stromazellen (MSC) in Europa beschrieben. Die Gewinnung von Zellen und die Weiterverarbeitung von MSCs werden durch europäische Direktiven (EUDs) geregelt. Vor Kurzem wurde die Verordnung für medizinische Produkte für fortgeschrittene Therapien (Advanced Therapies Medicinal Products; ATMPs) publiziert, die für die Produktion von MSCs in Europa von Bedeutung ist. Allerdings ist diese Gesetzgebung noch nicht abgeschlossen, obwohl sie sich im Endstadium befindet. MSCs werden derzeit in klinischen Studien - meist in Universitätskliniken - bei Patienten mit einer Vielzahl unterschiedlicher Erkrankungen erprobt. Unternehmen (kleine und mittlere Betriebe) sind mehr und mehr in die Produktion von MSCs für den Einsatz beim Menschen einbezogen. Da der Hauptzweck der Verordnung die Zulassung ist, wurde entschieden, ein Komitee für fortgeschrittene Therapien (Committee on Advanced Therapies; CAT) innerhalb der European Medicines Agency (EMEA) zu etablieren. Dieses CAT wird eine Stellungnahme zu Qualität, Sicherheit und Effektivität von ATMPs formulieren und für das Komitee für medizinische Produkte eine beratende und wissenschaftlich unterstützende Rolle spielen. Das Ziel dieser Übersicht ist die aktuelle Gesetzgebung, die für die Herstellung von MSCs von Bedeutung ist, kurz darzustellen.

\begin{tabular}{ll}
\hline KARGER & $\odot$ 2008 S. Karger GmbH, Freiburg \\
Fax +4976145207 14 & Accessible online at: \\
$\begin{array}{l}\text { E-mail Information@Karger.de } \\
\text { www.karger.com }\end{array}$ & www.karger.com/tmh
\end{tabular}

\section{KARGER}

www.karger.com
Ineke Slaper-Cortenbach, $\mathrm{PhD}$

Chair of the International Society for Cellular Therapy, European LRA Committee University Medical Center Utrecht

HP F03.821, Heidelberglaan 100, 3584 CX Utrecht, The Netherlands i.slaper@umcutrecht.nl 


\section{Introduction}

The collection of cells and tissues, that are being used as a source for multipotent mesenchymal stromal cells (MSCs) [1] - like bone marrow cells, cord blood or fat tissue -is regulated by the EUDs on quality and safety of tissue and cells. The MSC by itself is a medicinal product (MP) and falls under the EUDs on Medicinal Products. More recently, they are being regulated by the Advanced Therapy Medicinal Products (ATMPs) Regulation. This paper will outline important regulatory issues for the production of MSCs, but it will by no means cover all aspects. In general, each EUD contains the date when it enters into force, after it has been published in the Official Journal of the European Union [2]. Member States will then have another 2 years to transpose the directive into their national laws, regulations and administrative provisions. Regulations (like the Regulation on ATMPs (Regulation (EC) No 1394/2007) [3] are also published but do not require transposition. Furthermore, all individual Member States within the EU are entitled to add more stringent requirements in additional national laws, but it must be stated that those requirements are not within the scope of this paper.

\section{European Directive on Quality and Safety of Tissues and Cells}

Since cellular therapy is a field which involves a worldwide exchange of products, an urgent need was felt within the European Community to have a unified regulatory framework ensuring high standards of quality and safety of tissues and cells. The European Union (EU) in collaboration with the Council of Europe therefore published the European Directive 2004/23/EC [4] in the Official Journal of the European Union on April 7, 2004, entitled: 'Setting standards on quality and safety for the donation, procurement, testing, processing, preservation, storage and distribution of tissues and cells'. This so called 'Mother' Directive was followed in 2006 by two other implementing directives, of which only the first implementing directive (EUD 2006/17/EC) [5] is important for the production of MSCs. This EUD was published on February 8, 2006 and deals with the technical requirements for the donation, procurement and testing of human tissues and cells, including the donor selection and evaluation criteria. The second implementing directive (EUD 2006/86/EC) [6] defines the traceability requirements, notification of serious adverse reactions and events and certain technical requirements for the coding, processing, preservation, storage and distribution of human tissues and cells, which is not considered to be applicable for the production of MSCs, since MSCs are being regulated as ATMPs.

For the production of MSCs the following items mentioned in the 'Mother' Directive and in EUD 2006/17/EC are of major importance:
Table 1. Biological tests for IDM

\begin{tabular}{ll}
\hline Infectious disease & Biological test \\
\hline HIV-1,2 & $\begin{array}{l}\text { anti-HIV-1,2 } \\
\text { Hepatitis B } \\
\text { anti-HBc screening } \\
\text { anti-HCV antibody } \\
\text { Hepatitis C }\end{array}$ \\
Syphilis & $\begin{array}{l}\text { the presence of active Treponema pallidum } \\
\text { must be performed when donors are at risk }\end{array}$ \\
HTLV-1 &
\end{tabular}

$\mathrm{HBc}=$ Hepatitis B core antibody; HbsAg = hepatitis B surface antigen; HTLV-1 = human T-lymphotropic virus

- bone marrow procurement must be done in entities (or tissue establishments), which are licensed by the competent authority (CA) in the Member States or, if they are imported, must meet equivalent standards as described in EUD 2004/23/EC;

- donor selection criteria for MSC are described in Annex I of EUD 2006/17;

- infectious disease marker testing as described in Annex II of EUD 2006/17;

- the requirements for procurement as described in Annex IV of EUD 2006/17 (appropriate facilities, procurement materials and equipment etc);

- quality system must be implemented (SOPs, guidelines, training and reference manuals, reporting forms, donor records etc.);

- adverse events and reactions shall be notified to the CA;

- insurance of data protection and confidentiality;

- traceability of tissues and cells through laboratory identification procedures, record maintenance and an appropriate labelling system as described in ATMP Regulation Annex III;

- usage of a single European coding system (This is not yet finalized, but a CEN Workshop Agreement has recently been prepared, in which an extended ISBT 128 coding and labelling and usage of its terminology [7] (Therapeutic Cells (TC-MSC)) is proposed).

For the collection of cells, like bone marrow, donor selection, evaluation and the infectious disease marker (IDM) testing is essential. The biological tests for the IDM tests described in Annex II are the minimal requirements. If MSCs are being cultured from bone marrow, these tests must be performed on blood samples taken 30 days prior to donation. This window of testing is identical for Europe and the USA. However, in Europe the IDM testing is described in more detail, than by the Food and Drug Administration in the USA, because the EUD also specifies the type of test to be performed (table 1). In the USA, testing for HTLV-1 and -2 is also mandatory, while in Europe, this has only to be done for donors at risk. In Europe, additional typing of CMV, EBV etc. is not mandatory, but in case of third party MSC production more than relevant. 
Fig. 1. Clinical scale manufacture of MSCs in the context of European regulation.

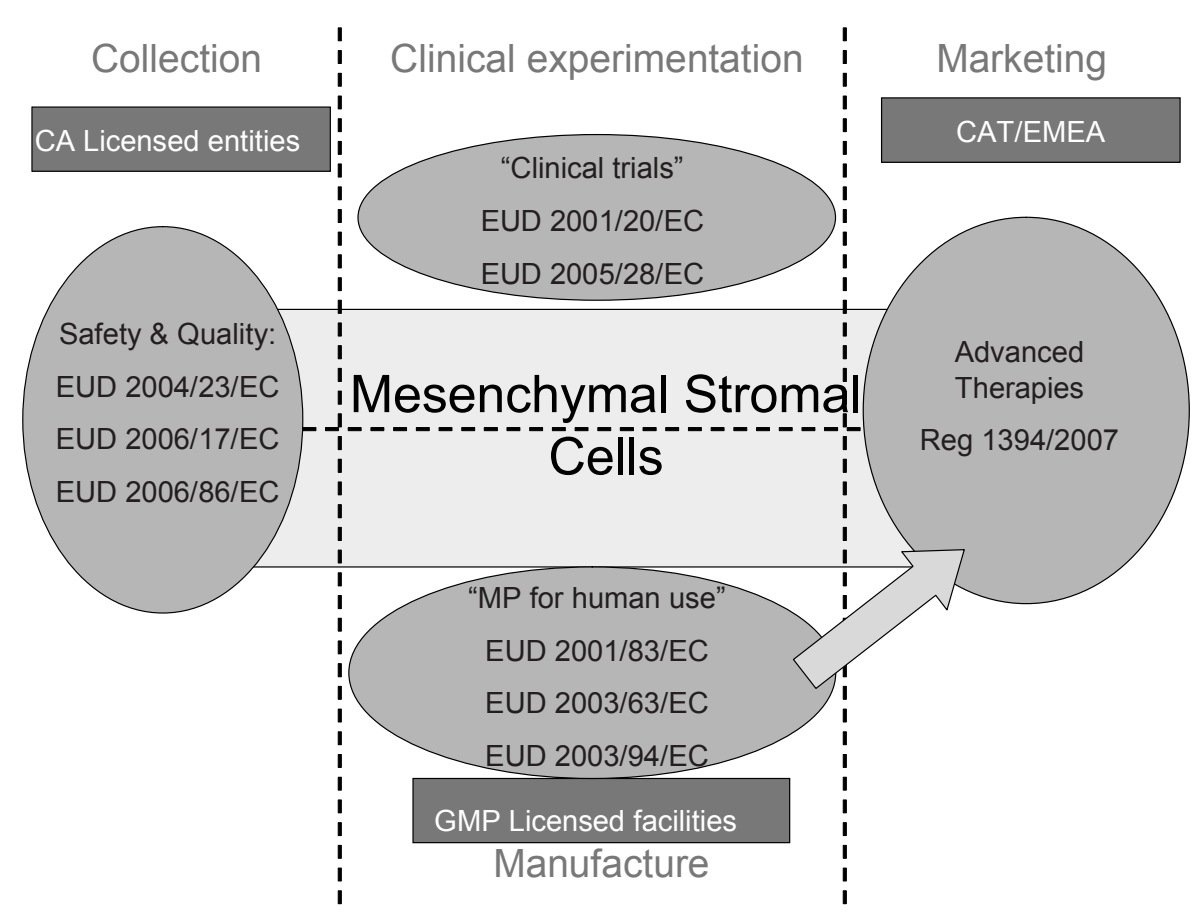

be observed for designing, conducting, recording and reporting clinical trials that involve the participation of humans. In article 13.3(a) of this EUD, it is stated that each batch of MPs needs to be manufactured according to the good manufacturing practice (GMP) for medicinal products for human use (Directive 2003/94/EC) [9]. The guidelines for GMP are also published and can be retrieved from the website of the European Commission as part of the EU Pharmaceutical legislation [10]: volume 4 of 'The rules governing medicinal products in the European Union'. It contains guidance for the interpretation of the principles and guidelines of GMPs for medicinal products for human and veterinary use. So, MSCs as part of a clinical trial need to be manufactured under GMP. In addition, it describes the documentation to be sent to the Ethics Committee as well as the Investigational Medicinal Product Dossier (IMPD). For all cellular products, including MSCs, it is still very difficult to complete an IMPD, and input of scientific committees in restructuring this pharmaceutical document for MP is, in my view, essential.

\section{EUD on Medicinal Products for Human Use}

The EU Directive 2001/83/EC [11] regulates products that are classified as MPs for human use and which are being industrially produced to be placed on the market. This EUD includes 2 types of products: somatic cell therapy MPs and gene therapy MPs. The Directive defines a MP as any substance or combination of substances presented for treating or preventing disease in human beings. Furthermore, it is stated that any substance or combination of substances, which may be admin- 
istered to human beings with a view to making medical diagnosis or to restoring, correcting or modifying physiological functions in human beings, is likewise considered a MP. In general, laboratories in academic hospitals do not fall under the scope of this EUD, but if a clinical trial is being conducted, the products will be classified as a MP, which have to be manufactured under GMP. In November 2005, it was decided to update this EUD because there was a regulatory gap in the legislation. New emerging therapies like tissue-engineered products were not covered by this EUD. So on November 16, 2005, the EU and the Council of Europe launched a proposal for the regulation of ATMPs.

\section{Advanced Therapies Medicinal Products}

The ATMP Regulation (Reg 1394/2007) has been published in the Official Journal on November 13, 2007 and will apply from 30 December 2008 onwards. The intention of this Regulation is to unify the regulatory framework for medical devices, tissue engineering and MPs. MSCs can be applied in all different forms of MPs, namely as somatic cell therapy MP, gene therapy MP or tissue engineered products. Engineering is defined as having been subject to substantial manipulation so that biological characteristics, physiological functions or structural properties relevant for the intended regeneration, repair or replacement are achieved. In most of the clinical trials, MSCs are engineered because they are subject to substantial manipulation. Expansion, culturing and/or coating on matrices, is not in the list in Annex I of this regulation, which defines manipulations that are not considered as substantial! In some clinical trials, for example the application of MSC for cardiac repair or MSC in the treatment of steroid resistant graft versus host disease, also fulfils the second condition for the status of engineering, namely: they are not intended to be used for the same essential function or functions in the recipient as in the donor. To determine the scope of this Regulation, the best option is to quote directly from the Regulation itself: 'ATMPs which are intended to be placed on the market in the MS and either prepared industrially or manufactured by a method involving an industrial process'. Excluded are: 'ATMPs which are prepared on a non-routine bases according to specific quality standards, and used within the same MS in a hospital under exclusive professional responsibility of a medical practitioner, in order to comply with an individual medical prescription, for a custom-made product for an individual patient'. Unfortunately, the intention of the scope is not yet clear. Vague are terms such as industrially produced, or what is defining an industrial process? If the MSCs are being produced in an academic hospital for the treatment of their own patient population, is this then also a production on a non-routine basis? Taking this one step further, can it be stated that all laboratories that manufacture MSCs in academic hospitals will need a GMP license by the CA? So far, certain issues still need to be resolved. In the Regulation it is stated that ATMP specific GCP and GMP guidelines will be developed after consulting EMEA.

So we will have to wait for more information, which will be given by the CAT of EMEA in the near future.

\section{References}

$\checkmark 1$ Horwitz EM, Le Blanc K, Dominici M, Müller I, Slaper-Cortenbach I, Marini FC, Deans RJ, Krause DS, Keating A: Clarification of the nomenclature for MSC: The International Society for Cellular Therapy position statement. Cytotherapy 2005;7(5): 393-395.

2 Easy access to the published documents (L stands for Legislation) in the Official Journal (OJ) of the European Union: http://eur-lex.europa.eu/en/index. htm.

3 Regulation (EC) No. 1394/2007 of the European Parliament and of the Council of 13 November 2007 on advanced therapy medicinal products and amending Directive 2001/83/EC and Reg (EC) No 726/2004 OJ L 324, 10-12-2007, pp 121-137.

4 Directive 2004/23/EC of the European Parliament and of the Council of 31 March 2004 on setting standards on quality and safety for the donation, procurement, testing, processing, preservation, storage and distribution of tissues and cells. OJ L 102, 07-04-2004, pp 48-58.

5 Commission Directive 2006/17/EC of 8 February 2006 implementing Directive 2004/23/EC of the European Parliament and of the Council as regards certain technical requirements for the donation, procurement and testing of tissues and cells. OJ L 38, 09-02-2006, pp 40-52.
6 Commission Directive 2006/86/EC of 24 October 2006 implementing Directive 2004/23/EC of the European Parliament and of the Council as regards traceability requirements, notification of serious adverse reactions and events, and certain technical requirements for coding, processing, preservation, storage and distribution of tissues and cells. OJ L 294, 25-10-2006, pp 32-50.

7 Ashford P, Distler P, Gee A, Lankester A, Larsson S, Feller I, Loper K, Pamphilon D, Poston L, Rabe F, Slaper-Cortenbach I, Szczepiorkowski Z, Warkentin P: Standards for the terminology and labeling of cellular therapy products. Transfusion 2007 47(7):1319-1327.

8 Directive 2001/20/EC of the European Parliament and of the Council of 4 April 2001 on the approximation of the law, regulations and administrative provisions of the MS relating to the implementation of good clinical practice in the conduct of clinical trials on medicinal products for human use. OJ L121, 01-05-2001, pp 34-44.

9 Commission Directive 2003/94/EC of 8 October 2003 laying down the principles and guidelines of good manufaturing practice in respect of medicinal products for human use and investigational medicinal products for human use. OJ L 262 14-10-2003, pp 22-26.
10 GMP guidelines: http://ec.europa.eu/enterprise/ pharmaceuticals/eudralex/vol4_en.htm.

11 Directive 2001/83/EC of the European Parliament and of the Council of 6 November 2001 on the Community code relating to medicinal products for human use. OJ L 311, 28-11-2001, pp 67-128.

\section{Websites for Further Information}

ISCT European LRA Committee: www.celltherapysociety.org/Committees_Working_Groups/ Committees/Regulatory_Affairs_Europe.aspx.

EU DG Sanco: Quality and Safety of tissues and cells: http://ec.europa.eu/health/ph_threats/human_substa nce/tissues_en.htm.

EU DG Enterprise and Industry: Advanced Therapies: http://ec.europa.eu/enterprise/pharmaceuticals/advth erapies/advanced_en.htm.

EMEA: www.emea.europa.eu.

ISBT 128 Labelling: $w w w . I C C B B A . o r g$. 